\title{
Impact of Conventional Cattle Farming Systems on Farmer Awareness, Livestock Output and Household Income
}

\author{
Pengaruh Sistem Peternakan Sapi Konvensional terhadap Kesadaran Peternak, Hasil Ternak dan \\ Pendapatan Rumah Tangga
}

D. A. Iyai, D. Nurhayati, S. Pakage, \& I. Widayati

Department of Animal Production, Faculty of Animal Sciences, Papua University

J1. Gunung Salju, Amban, Manokwari, Papua Barat Province.

*Corresponding author: da.iyai@yahoo.com

(Received 12-07-2020; Revised 30-08-2020; Accepted 26-09-2020)

\begin{abstract}
Cattle was introduced in Papua a long time ago. However, it was unpredictable to adapt to raise cattle. An explorative field study was performed in fifteen villages using participatory research to better understand the dynamics of cattle performances. Cattle farming system has been categorized in three types, i.e. small- and medium-sized systems. They used ANOVA and Kruskal-Wallis to analyze data. The finding of this research was that the three sizes of cattle farming in many components of good farming practices were similar $(\mathbf{p}>\mathbf{0 . 0 5})$. No large gap was found along the lines of farmers, cattle, and economic performance. West New Guinea's Tropical Livestock Unit was low and has the potential to increase due to agribusiness potential. Better government services and other related stakeholders should narrow the lack of good agricultural practices.
\end{abstract}

Keywords: Cattle, production of farmers, conventional farming method, agribusiness, West New Guinea.

\begin{abstract}
ABSTRAK
Ternak sapi sudah lama diperkenalkan di Papua. Namun, tidak dapat diprediksi bagi peternak asli Papua untuk beradaptasi dengan beternak sapi yang baik. Kajian eksplorasi lapang telah dilakukan pada lima belas desa dengan menggunakan penelitian partisipatif untuk lebih memahami dinamika performans ternak. Sistem budidaya sapi dikategorikan menjadi tiga jenis, yaitu sistem skala kecil dan menengah. Data dianalisis dengan ANOVA dan Kruskal-Wallis. Temuan kajian adalah bahwa ketiga ukuran peternakan sapi dalam berbagai komponen praktik budidaya yang baik memiliki kemiripan (p>0.05). Tidak ditemukan kesenjangan yang besar di sepanjang garis petani, sapi, dan kinerja ekonomi. Satuan Peternakan Tropis di Papua Barat cukup rendah dan berpotensi ditingkatkan karena potensi agribisnis tersedia. Layanan pemerintah yang lebih baik dan pemangku kepentingan terkait lainnya harus mempersempit berkurangnya praktik pertanian yang baik.
\end{abstract}

Kata kunci: Sapi, produksi peternak, metode usahatani konvensional, agribisnis, Papua Barat.

\section{INTRODUCTION}

Cattle is one of the Asia's exotic and conventional animal farms (Devendra 2007), including in Indonesia (Utomo \& Widjaya 2007) and in Papua particular (Hartono $\&$ Widayati 2011). In Papua, the rank of cattle is after pigs, the and native chicken. Several animal farms had been introduced since 1963 during the Ducth period, such as pigs, rabbits, chicken and dairy cattle. Several animal farms have been introduced since 1972 in the exchange of Ducth administration with Indonesia, i.e. Cattle, goat and duck in
Merauke-Papua. Both livestock projects were established under the administration of Indonesia by designing several related and relevant programs (Bahri et al. 2004). Presidential assistance, low-developed village system (Widi 2015; Iyai et al. 2016), and direct community assistance were designed programs a such. Less information about productivity of cattle farming has been published since then. This leads to the development of livestock farming systems which has been implemented behind the national average productivities. 
In the context of the Papua Barat and particularly the Manokwari regency, cattle population estimated are 37,212 head and 20,829 head respectively. Local Papuan farmers are raising cattle with little effort and encouragement by the use of their local resources because of the third rank places of the cattle for the local Papuan farmers. Their wellbeing is expected to have changed slower than that of non-Papuan ethnic (trans migrants). The cattle that each farmer raises in the Papua Barat province are less than counted by Hartono \& Widayati (2011). The causes of this achievement by local Papua farmers are due to unqualified and less experiencing local Papuan farmers in keeping their cattle. Thus, while it's been practiced for a long time, adaptation inkeeping cattle is still questionable.

Local Papuan farmers prone to keep the cattle with lower productivity compared to the non-Papuan farmers. Added to this, the local farmers tend to use no external and internal inputs, such as silages, roughages and additive feeds.. It causes decreasing in the productivity from farmers and output in resulted from the cattle. Local Papuan farmers do not have any experience because of the implementation with less even no extension programs. This is a common situation that Papuan livestock farmers are being experienced (Supriadi 2008). They do not even know what nutritional composition is should be provided for the cattle (Haryanto 2009; Nulik \& Hau 2005) and what management is appropriate applied in the cattle rearing (Sudaryanto \& Jamal 2000). The latter becomes so important and plays a role in the resource design and application. Iyai \& Chrisostomus (2013) have identified several livestock farming systems, and the focus of this article is on the traditional cattle farming systems practicing by the local Papuan farmers. The aim of this study was to analyze the performances of the farmers productivities in the several groups of cattle farming systems. The core investigation of this research was primarily conducted to investigate how well conventional cattle farming systems are practiced by using inputs, and outputs resulted in the livestock farming cycle (Sudaryanto \& Jamal 2000).

\section{MATERIALS AND METHODS}

In Manokwari regency an explorative-field case study was conducted and involved six districts, i.e. District of North Manokwari, district of east Manokari, district of West Manokwari, district of Warmare, district of Prafi and district of Masni. The regency of Manokwari, which has a total area of $14,445 \mathrm{~km}^{2}$, has a population of approximately 161,000 heads with a density of 11.51 head $\mathrm{km}^{-1}$ and is located at $132^{\circ} 30^{\prime}-134^{\circ} 45^{\prime}$ East Meridian and $0^{\circ} 20^{\prime}-$ $2^{\circ} 25^{\prime}$ South Latitude (Figure 1).

Manokwari's population is increasing both in urban and rural areas, especially in transmigration areas such as districts Prafi and Masni. Local extension staffs guided the selected respondents, who originated in 14 villages, i.e. Warbefor, Bremi, Susweni, Amban, Fanindi, Tanah Merah, Nimbai, Aimasi, Mokwam, Mimbowi, Wosi, Waseki, and SP-08. Several villages have been selected and sampled using snowball process.
Study method was Participatory Situation Analysis (PSA) used to gathering data and information from farmers and observing livestock performances on the household farms (Conroy 2005). Interviews were performed using questionnaires to collect information from selected farmers. Farmers were asked questions of 36 opened and closed semi-structured questions, i.e. farmers' characteristics, farming performance characteristics, and cattle production and breeding performance characteristics. Time spent was about 70 minutes. This field work took 15 days to complete.

Parameters used in measuring the objectives consisted of farmers' performances, i.e. ages of households ( $\mathrm{yr} / \mathrm{hh})$, family size (head/hh), livelihood (types/hh), educational level (basic to higher university/hh), working time $(\mathrm{hr} / \mathrm{hh})$, and farmers knowledge in technical cattle management, i.e. knowledge of selection, mating signs, pregnant detection, forages, grass quality, cattle housing, disease knowledge, disease prevention, utilization and kind of products. Cattle performance consisted of herd size (head/hh), parental stock (head/hh), mating period $(\mathrm{d} / \mathrm{hh})$, forages frequency (times/hh), and offered forages (times/hh). Agribusiness beneficiary consisted of the market gate prices on each ages categorical (IDR/head/hh), i.e. male calf, female calf, young steer, young heifer, adult steer, and adult heifers.

In Excel 2010 qualitative and quantitative data have been reached. Several qualitative data were made using coding scales, i.e. health, education, range, match sign, pregnant detection to type of product. Classification was based on three sizes of cattle farming systems in three Manokwari, i.e. coastal and lowland Manokwari, agroecological zones. Then there was mathematical formula, where variable responses are. The overall mean effect is the size of the farming system, i.e. 1 is small-scale, 2 is medium-scale and 3 is large-scale cattle farming systems and errors with normal distribution, $\mathrm{N}(0, \mathrm{I})$. Data normality testing was performed using Kolmogorov-Smirnov and Shapiro-Wilk. Data is usually distributed when the p-value of the evaluated variables reaches 0.05 ( $p>0.05)$.

One-way Anova (Ott \& Longnecker 2001) was used to evaluate the data for the normally distributed parameters. Data review using version 18.0 of SPPS, was used. Information normally distributed were ages of producers, and adult bovine prices. Several data were found with not normally distributed, after testing for data normality. Nonnormality data included health, schooling, hours of work, selection, mating, pregnant identification, forage supply, grass quality, forage supply, cattle accommodation, diseases of information, prevention of diseases, usage and product type. Using Square root (sqrt), each variable was then transformed. The square root (sqrt) transform formula is $(\mathrm{Y}+1 / 2)^{1 / 2}$ that has been created to obtain data normality. Then analyzed nonparametric data using Kruskal-Wallis (H). Kruskal-Wallis' (1952) formula is equivalent to

$$
\mathrm{H}=\frac{1}{S^{2}} \times\left[\sum_{i} \frac{R_{i}^{2}}{r_{i}}-\frac{N(N+1)^{2}}{4}\right]
$$

Post-hoc analysis of Scheffe was performed for knowing which samples were significant difference $(p<0.05)$ 


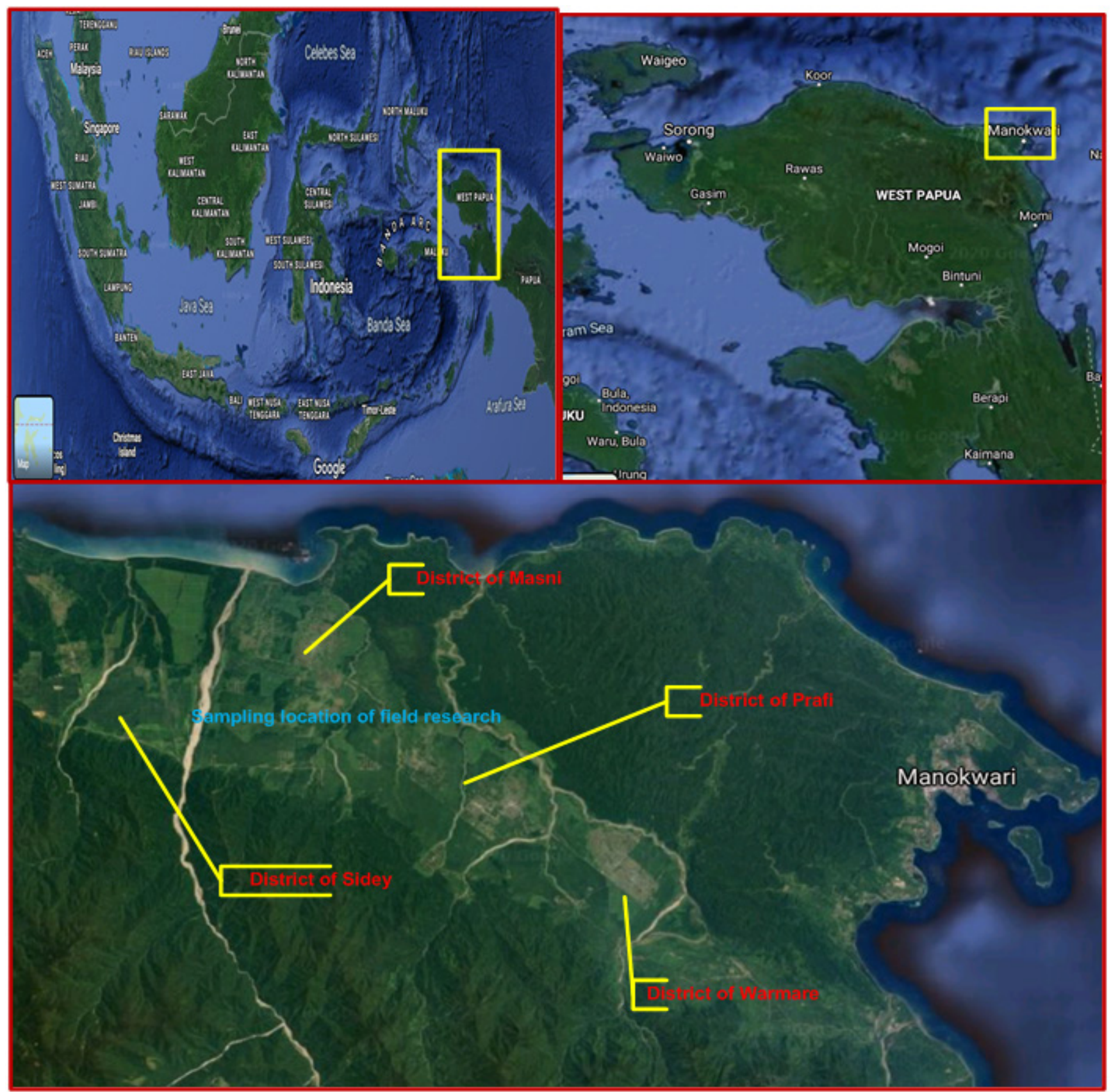

Figure 1. Sampling location of cattle farmers' survey in Manokwari, Papua barat-West New Guinea

(Ott \& Longnecker 2001). Mental model of cattle farming systems was developed using version 15.0 of Microsoft Visio.

\section{RESULTS AND DISCUSIONS}

\section{Farmers performance}

The age of Manokwari cattle farmers was at productive levels, and identical between scales $(\mathrm{p}>0.05)$ (Table 1). Large-scale farmers may have raised cattle first, followed by small and medium-scale farmers. Hence, they have been built in time. It's been found in experiences too. Though not significantly different $(\mathrm{p}>0.05)$, it was consistent with the ages that larger-scale farmers have higher experiences than medium and small-scale farmers.
There was also similar family number residing in each household $(\mathrm{p}>0.05)$. Compared with medium and small scales, large-scale farmers had a higher number. Most farmers in Thailand were categorized into moderate cattle farmers (Suppadit et al. 2006). The cattle farmers in Manokwari's ordinary livelihood was restricted to as farmers and few found doing private works. Small stores are frequently found in Manokwari. The farmers' history was in elementary school level of general education. Thailand 's education had effect on Thailand's cattle farmers' successful agricultural practices (GAPs) (Suppadit et al. 2006). The farmers' allocated working time for tethered cattle was less than three hours. It means cattle were released under secondary forest and palm oil trees in several communal lands. 
Iyai et al.

Jurnal Ilmu Produksi dan Teknologi Hasil Peternakan 8 (3): 144-150

Table 1. Performances of traditional cattle farmers in Manokwari, Papua Barat.

\begin{tabular}{|c|c|c|c|c|c|c|c|c|c|}
\hline \multirow[t]{3}{*}{ Farmers' Performances } & \multicolumn{6}{|c|}{ Scale of groups } & \multirow{2}{*}{\multicolumn{2}{|c|}{ Total $(\mathrm{N}=44)$}} & \multirow[t]{3}{*}{$\mathrm{p}$} \\
\hline & \multicolumn{2}{|c|}{ Small $(n=20)$} & \multicolumn{2}{|c|}{ Medium $(n=17)$} & \multicolumn{2}{|c|}{ Large $(n=7)$} & & & \\
\hline & Mean & SD & Mean & SD & Mean & SD & Mean & SD & \\
\hline Ages $(y)^{1}$ & 41.2 & 11.9 & 45.6 & 7.6 & 47.9 & 12.7 & 44.9 & 10.7 & NS \\
\hline Experience $(y)^{1}$ & 10.0 & 5.4 & 13.1 & 5.8 & 14.5 & 7.3 & 11.9 & 6.0 & NS \\
\hline Family (head) ${ }^{1}$ & 4.5 & 1.0 & 4.4 & 1.4 & 5.3 & 1.8 & 4.6 & 1.3 & NS \\
\hline Livelihood $^{2}$ & 1.0 & 0.2 & 1.0 & 0.0 & 1.0 & 0.0 & 1.0 & 0.1 & NS \\
\hline Education $^{2}$ & $2.1 \mathrm{a}$ & 1.2 & $1.3 b$ & 0.8 & $1.0 \mathrm{c}$ & 0.0 & 1.6 & 1.0 & 0.00 \\
\hline Workingtime (h) & $1.1 \mathrm{a}$ & 0.3 & $1.6 \mathrm{~b}$ & 0.5 & $1.6 \mathrm{~b}$ & 0.5 & 1.4 & 0.5 & 0.03 \\
\hline \multicolumn{10}{|l|}{ Farmers' knowledge } \\
\hline Selection $^{2}$ & $1.2 \mathrm{a}$ & 0.4 & $1.6 b$ & 0.5 & $1.9 \mathrm{c}$ & 0.4 & 1.5 & 0.5 & 0.00 \\
\hline Mating sign ${ }^{2}$ & 1.9 & 0.3 & 1.8 & 0.3 & 2.0 & 0.0 & 1.9 & 0.2 & NS \\
\hline Pregnant Detection ${ }^{2}$ & 1.3 & 0.5 & 1.2 & 0.4 & 1.1 & 0.4 & 1.2 & 0.4 & NS \\
\hline Provided forage $^{2}$ & 1.1 & 0.3 & 1.4 & 0.5 & 1.4 & 0.5 & 1.3 & 0.4 & NS \\
\hline Grass Quality $^{2}$ & 1.6 & 0.5 & 1.7 & 0.4 & 2.0 & 0.0 & 1.7 & 0.4 & NS \\
\hline Cattle housing $^{2}$ & 1.1 & 0.2 & 1.1 & 0.2 & 1.0 & 0.0 & 1.1 & 0.2 & NS \\
\hline Disease knowledge $^{2}$ & 1.2 & 0.4 & 1.1 & 0.3 & 1.1 & 0.4 & 1.2 & 0.4 & NS \\
\hline Diseases prevention $^{2}$ & 1.7 & 0.5 & 1.7 & 0.5 & 1.3 & 0.5 & 1.6 & 0.5 & NS \\
\hline Utilization $^{2}$ & $1.1 \mathrm{a}$ & 0.2 & $1.5 \mathrm{~b}$ & 0.5 & $1.3 \mathrm{c}$ & 0.5 & 1.2 & 0.4 & 0.01 \\
\hline Kind of product ${ }^{2}$ & 1.1 & 0.2 & 1.3 & 0.7 & 1.0 & 0.0 & 1.1 & 0.5 & NS \\
\hline
\end{tabular}

${ }^{1)}$ Anova (F-test), $\mathrm{p}<0.05,{ }^{2} \mathrm{NPar}-\mathrm{test}=$ Kruskal-Wallis $(\mathrm{H}), \mathrm{p}<0.05$. NS: Not Significant. Different superscripts indicated significant difference at $\mathrm{p}<0.05$.

Farmers had not nearly selected the cattle as breed. Identifying mating time was also found small number in few farmers as well as detecting pregnant cows. Farmers' knowledge of cattle rearing had not been sufficient as recruited in livestock management. Several farmers provided forage for cattle and most cattle farmers did not. Farmers planted the quality of the grasses had yielded sufficient low nutrient content. Low nutrient content found in seminatural grasses (Niemela et al. 2008). The experiences demonstrated by farmers from the Central Java using paddy leaves. Ammonization and fermentation were then applied to boost the nutrient content of paddy leaves (Nurcholidah et al. 2013; Muslim 2006). Manokwari's cattle farming systems were primarily managed withoutshed for the cattle, i.e. free-range cattle farming systems. In Kenya condition, farmers had similar experience reported by Ohaga et al. (2015).

Livestock farmers did not have sufficient knowledge of the animal diseases. While in Kenyan as Ohaga et al. (2007) had reported, animal diseases found are Trypanosomosis, East Coast Fever, Anasplasmosis, Helminthosis, Anthrax, Food and Mouth. Helminthiases, however, could have immense infestation in Indonesia under tropical systems. Thus, disease prevention had rarely been practicing. Compared to the West Papuan farmers, Kenyan farmers had identified diseases. Usage of cattle was achieved by selling livestock and by drought. The cattle were never used as support for the livestock. In comparison, livestock farmers in Kenya used cattle intensively as support for animals (Ohaga et al. 2007). Variaty of cattle products in Manokwari were meat, cow hide and feces. The cow hide was processed as fast food (Kerupuk, in Bahasa). Many farmers in Papua had extensive application of biofuel (Widodo \& Hendriadi 2005). Another use of cattle products is bio-fertilizer that has been applied intensively by farmers in Low land Manokwari, Upland areas (Thanner et al. 2001), Middle Java (Nurcholidah et al. 2013) and Mid-Hill Nepal (Thanner \& Tanner 2002).

\section{Cattle performance}

Significant difference in herd size of cattle raised by Manokwari farmers $(\mathrm{p}<0.000)$ (Table 2). On average, smallholder farmers had held just $2.5 \pm 0.9$ head/h. Mediumand large-scale cattle farmers subsequently doubled, i.e. $6.5 \pm 0.8$ head / h and 12.9 \pm 1.6 head / h, respectively. Bali cattle were an introduced and raised commonly locally in West New Guinea Papua. The herd size held by farmers in Manokwari was lower than in Jawa Tengah / Java Center (Nurcholidah et al. 2013), i.e. 14.6 livestock unit. Tropical Livestock Unit size in Mid-Hill Nepal was 4-6 (Thorne \& Tanner 2002). Widayati \& Suawa (2007) divided cattle farmers in Sarmi-Papua into three classes, i.e. cattle keepers 1-2 head / h, 3-6 head / h and 7-10 head / h. Farm size in Thailand becomes a significant component of cattle performance determination (Suppadit et al. 2006). In Kenya as Ohaga et al. (2007), a relatively varied herd size, i.e. 2-23 head / h (median of 2).

Between the three scales ( $p>0.05)$, i.e., 2 livestock units, the parental stock of cattle owned by farmers in Manokwari was marginally similar. In planning future livestock production in Indonesia, parental stock becomes 
Iyai et al.

Jurnal Ilmu Produksi dan Teknologi Hasil Peternakan 8 (3): 144-150

Table 2. Cattle performances in Manokwari, Papua Barat.

\begin{tabular}{|c|c|c|c|c|c|c|c|c|c|}
\hline \multirow{3}{*}{$\begin{array}{l}\text { Performance } \\
\text { Cattle }\end{array}$} & \multicolumn{6}{|c|}{ Scale of groups } & \multirow{2}{*}{\multicolumn{2}{|c|}{ Total $(\mathrm{N}=44)$}} & \multirow[t]{3}{*}{$\mathrm{p}$} \\
\hline & \multicolumn{2}{|c|}{ Small $(n=20)$} & \multicolumn{2}{|c|}{ Medium $(n=17)$} & \multicolumn{2}{|c|}{ Large $(n=7)$} & & & \\
\hline & Mean & $\mathrm{SD}$ & Mean & $\mathrm{SD}$ & Mean & $\mathrm{SD}$ & Mean & SD & \\
\hline Herd size $(\text { head })^{1}$ & $2.5 \mathrm{a}$ & 0.9 & $6.5 b$ & 0.8 & $12.9 \mathrm{c}$ & 1.6 & 5.7 & 3.8 & 0.00 \\
\hline Parental stock (head) ${ }^{1}$ & 2.4 & 0.3 & 2.3 & 0.2 & 2.7 & 0.1 & 2.4 & 0.3 & NS \\
\hline Mating period $(d)^{1}$ & 66.7 & 17.3 & 69.0 & 22.4 & 56.4 & 16.8 & 65.9 & 19.4 & NS \\
\hline Forage freq(times $)^{1}$ & 2.4 & 0.5 & 2.3 & 0.5 & 2.6 & 0.5 & 2.4 & 0.5 & NS \\
\hline Offered Forages ${ }^{2}$ & $1.1 \mathrm{a}$ & 0.2 & $1.1 \mathrm{~b}$ & 0.2 & $2.0 \mathrm{c}$ & 0.0 & 1.2 & 0.4 & 0.00 \\
\hline
\end{tabular}

${ }^{1)}$ ANOVA (F-test), $\mathrm{p}<0.01$, NS: Not Significant. Different superscripts indicated significant difference at $\mathrm{p}<0.05$.

significantly more critical (Ilham 2007). That should be done to improve cattle of genetic quality. Cattle matting time entering the reproductive cycle was close between the three systems $(p>0.05)$. Similar forage frequency in the entire cattle farming scales $(p>0.05)$ was performed. Because of the free-range cattle farming systems embraced by conventional cattle farmers, forages provided to cattle were less than anticipated. Themeda arguens, Paspalum conjugatum, Digitaria sp, Imperata cylindrica, Cyperus rotundus and Eleusine indica were wastes from agricultural crops that used in East Java by cattle farmers (Winarso et al. 2005). Alternative forages should therefore be prepared for the cattle as reported in Asia by (Widi 2015), Devendra \& Sevilla (2002).

In West New Guinea cattle farming system needs some improvement. Nulik \& Hau (2005) had shown their work in East Nusa Tenggara to improve the quality of nutrient from local forages. Glirisedia sepium, Leucaena leucocephala and Sesbania glandiflora were applied at the local forages. Such forages were made in cube and pellet shapes. Compared to pellets with ample nutrient content the cube was the chosen one. East Java documented best practices for the application of livestock forage (Anggraeni et al. 2006; Anggraeni et al. 2008). Therefore, Bahri (2004) recommended several issues to be promoted for improving cattle farming systems in Indonesia, i.e. breeds, feeds, policy, veterinary and food security and post-harvesting. Ilham (2007) found that national livestock feeds, and cattle breeds also suggested the issues highlighted.

\section{Performances of Economics}

Cattle farms' agribusiness was evaluated in the net benefits of cattle farm. Varied sold were the cows, weaned cows, grower, and adult bovine animals. Young steer bovine prices ranged from IDR 4 millions to IDR 5 million rupiah (equal to US\$ 400-500) (Table 3). Young heifer bovine prices ranged from IDR 4.1 million to IDR 4.7 million rupiah (US\$ 410-470). The prices are usually rendered in Indonesia based on the basic mathematical formulae, i.e. Prices of cattle equal to cattle weight 0.50 depend on the price per $\mathrm{kg}$ of meat.

No variations in the prices of sold cattle were noticed in Manokwari $(\mathrm{p}>0.05)$. It means the prices of sold cattle were more influenced by the farmers and middlemen in Manokwari. The prices of young heifer was higher than that the rest followed by the adult steer, and adult heifer (Table 3 ). The expensiveness of the young heifer was probably due to breed types and objectives in cattle rearing. Where the young heifer will be used as breed than the prices will rise up. Similar finding was also reported in Merauke, Papua, Yogyakarta and Belanda (Ocaido et al. 2009; Nurcholis et al. 2019; Widi 2015; Oosting et al. 2017). Compared to cattle farmers, the middle man had a high benefit of income (Widayati \& Suawa 2007). Because it is a conventional market, many attempts have been made by farmers and buyers to maintain the prices of the cattle. Bambar et al. (2019) has published similar findings in Lampung. The small-scale cattle farms tend to sell high-priced cattle to gain cash as farm continuity capitals. Whereas the other two were lower than those of small-scale cattle farming. Therefore,

Table 3. Agribusiness of traditional cattle farming system in Manokwari, Papua Barat.

\begin{tabular}{|c|c|c|c|c|c|c|c|c|c|}
\hline \multirow{3}{*}{$\begin{array}{l}\text { Category of cattle based } \\
\text { on ages }\end{array}$} & \multicolumn{6}{|c|}{ Cattle prices based on Scale of groups (IDR)* } & \multirow{2}{*}{\multicolumn{2}{|c|}{ Total $(\mathrm{N}=44)$}} & \multirow[t]{3}{*}{$\mathrm{P}$} \\
\hline & \multicolumn{2}{|c|}{ Small $(n=20)$} & \multicolumn{2}{|c|}{ Medium $(n=17)$} & \multicolumn{2}{|c|}{ Large $(n=7)$} & & & \\
\hline & Mean & SD & Mean & SD & Mean & SD & Mean & SD & \\
\hline Adult steer $^{1}$ & 5.352 .000 & 949.720 & 5.264 .700 & 615.360 & 4.785 .710 & 128.637 & 5.215 .900 & 898.300 & NS \\
\hline Adult heifer ${ }^{1}$ & 4.125 .000 & 930.120 & 4.794 .110 & 662.820 & 4.357 .140 & 110.733 & 4.420 .450 & 901.280 & NS \\
\hline Young steer ${ }^{1}$ & 1.190 .000 & 335.449 & 1.129 .411 & 211.437 & 1.114 .285 & 260.950 & 1.154 .545 & 277.408 & NS \\
\hline Young heifer ${ }^{1}$ & 8.900 .000 & 836.660 & 8.794 .110 & 685.990 & 8.928 .570 & 838.08 & 8.863 .630 & 765.260 & NS \\
\hline Male calf ${ }^{1}$ & 1.925 .000 & 410.231 & 2.058 .823 & 511.198 & 1.714 .285 & 367.099 & 1.943 .181 & 452.074 & NS \\
\hline Female calf ${ }^{1}$ & 1.425 .000 & 276.966 & 1.405 .882 & 272.650 & 1.371 .428 & 309.377 & 1.409 .090 & 274.343 & NS \\
\hline
\end{tabular}

${ }^{1)}$ Anova (F-test), p>0.05, NS: Not Significant. *IDR.10.000=USD 1. 
Adnyana (2000), cited in Indonesia by Sudaryanto \& Jamal (2000), has established cattle agri-business. Winarso et al. (2005) stated other records of economic dimension in East Java-Indonesia. Income gained from cattle rearing had an important determination on good farming practices (GAPs) in Thailand (Suppadit et al. 2006). The farmers of South Sulawesi were also experiencing positive good agricultural practices (Basuno \& Sehaeti 2007). We said that GAPs are very much defined by the human resources capacities that are accessible and ready to work. In closing with Winarso et al. (2005), the success story of beef cattle production in East Java is the convergence of livestock and farm agribusiness. Likewise, in Manokwari-Papua Barat, cattle production has been showing low productivity. It is therefore needs intensive improvement particularly in breeds of cattle, proper cattle management, and quality forages for cattle.

\section{CONCLUSIONS}

Performances of cattle farmers in Manokwari differed on education and working hours including selection knowledge, and utilization. The rest have no differences. Cattle performances vary on herd size, nad offered feeds. No difference found in economical performances. The success of the farmers would have a significant determinant factor in forming the method of cattle rearing. It is therefore in the near coming years, cooperation is required on the integration of livestock with agriculture of farming sector. The first two elements for further development are race and feeding. Forages with a low nutrient content will need technologies such as ammonization and fermentation for feeding. Good Agricultural Practices (GAPs) will be determined by the human resources available and capacity. Extension is a small technical aspect that requires further activities under traditional system of cattle farming.

\section{ACKNOWLEDGMENT}

Authors thanked Dadan, S.Pt. for sharing data of cattle performances in Manokwari. Special thanks were given to the whole cattle farmers as participants during field visits in several villages both in coastal and lowland agro-ecological zones of Manokwari. We also thanked blind reviewers for improving manuscript readable and ready in publish.

\section{REFERENCES}

Anggraeni, Y. N., U. Umiyasih, D. Pamungkas, \& Aryogi. 2006. Potensi bahan pakan Inkonvensional Asal Limbah Pertanian dan Perkebunan di Beberapa Kabupaten di Jawa Timur. Seminar Nasional Teknologi Peternakan dan Veteriner. Hal.: 891-899.

Anggraeni, Y. N., \& U. Umiyasih. 2008. Evaluasi Potensi Pakan Asal Limbah Tanaman Pangan dan Limbah Perkebunan di Daerah Prioritas Kawin Alam Pendukung Program P2SDS. Seminar Nasional Teknologi Peternakan dan Veteriner. Hal. 304-311.

Bahri, S., B. Setiadi, \& I. Inounu. 2004. Arah penelitian dan pengembangan Peternakan Tahun 2005-2009. Seminar nasional teknologi peternakan dan veteriner
2004. P. 6-10.

Basuno, E., \& R.N. Suhaeti. 2007. Analisis bantuan pinjaman langsung masyarakat (BPLM); kasus pengembangan usaha ternak sapi di provinsi Sulawesi Selatan. Analisis kebijakan pertanian. 5(2):150-166.

Conroy, C. 2005. Participatory livestock research; a Guide. ITDG publishing. Warwickshire. UK.

Devendra, C. 2007. Perspectives on animal production systems in Asia. Livestock science 106 (2007) 1-18.

Devendra, C., \& C.C. Sevilla. 2002. Availability and use of feed resources in crop animal systems in Asia. Agricultural systems 71 (2002) 59-73.

Devendra, C., \& D. Thomas. 2002. Smallholder farming systems in Asia. Agricultural systems 71 (2002) 17-25.

Diwyanto, K., B. R. Prawiradiputra, \& D. Lubis. 2001. Integrasi Tanaman Ternak dalam Pengembangan Agribisnis yang Berdaya Saing, Berkelanjutan dan Berkerakyatan. Seminar Nasional Teknologi Peternakan dan Veteriner 2001. Hal.: 17-26.

Hartono, S., \& T. W. Widayati. 2013. An alternative approach to meet beef self-sufficiency in West Papua. J. Indonesian Trop. Anim. Agric. 36 (3) September. Diponegoro University, Semarang.

Ilham, N. 2007. Alternatif kebijakan peningkatan pertumbuhan PDB Subsektor peternakan di Indonesia. Analisis kebijakan pertanian. Vol. 5. No. 4. Desember 2007. Hal.: 335-357.

Indraningsih, R. Widyastuti, \& Y. Sani. 2006. Limbah Pertanian dan Perkebunan Sebagai Pakan Ternak; Kendala dan Prospek. Lokakarya Nasional Ketersediaan IPTEKS dalam pengendalian penyakit strategis pada ternak ruminansia besar. Hal.: 99-105.

Iyai, D.A., \& H. Y. Chrisostomus. 2013. Scoping, Pemodelan dan Kuantifikasi Sistim-Sistim Peternakan Terpadu di Manokwari, Papua Barat. Laporan Penelitian. Fakultas Peternakan Perikanan dan IlmuKelautan. UniversitasNegeri Papua. Manokwari.

Kusnadi, U., S. Iskandar, \& M. Sabrani. 1993. Research methodology for crops-animal systems in Hilly Areas of Indonesia. (Ed). C. Devendra dan C. Sevilla. Proceedings of an International Workshop. CropAnimal Interaction. IRRI Discussion Paper Series No. 6. IRRI Philippines.

Kusnadi, U. 2008. Inovasi teknologi peternakan dalam sistim integrasi tanaman-ternak untuk menunjang swasembada daging sapi. Jurnal pengembangan inovasi pertanian. 1 (3): 189-205.

Muslim, C. 2006. Pengembangan sistim integrasi paditernak dalam upaya pencapaian swasembada daging di Indonesia: Suatu tinjauan evaluasi. Analisis kebijakan pertanian. Vol. 4. No. 3. September 2006. Hal. 226-239.

Niemela, M., A. Huuskonen, S. Jaakola, E. JokiTokola, \& M. Hyvarinen. 2008. Coastal meadows as pastures for beef cattle. Agriculture, Ecosystem and Environment 124 (2008) 179-186.

Nulik, J., \& D. K. Hau. 2005. Pembuatan dan pemanfaatan pakan awet pada ternak sapi bali timor. Seminar nasional teknologi peternakan dan veteriner 2005.

Nurcholidah, A. Sodiq, \& K. Muatip. 2013. Kinerja usaha 
peternakan sapi potong sebelum dan setelah mengikuti program Sarjana Membangun Desa Periode 20082012. Jurnal ilmiah peternakan, 1(3): 1183-1191.

Ohaga, S. O., E. D. Kokwaro, I. O. Ndiege, A. Hassanali, \& R. K. Saini. 2007. Livestock farmer's perception and epidemiology of bovine trypanosomiasis in Kwale District, Kenya. Preventive veterinary medicine. 80 (2007) 24-33.

Ott, R. L. \& M. Longnecker. 2001. An introduction to statistical methods and data analysis. 5thEdition.Texas A \& M University. Wadsworht Group USA.

Priyanti, A., T. D. Soedjana, R. Matondang, \& P. Sitepu. 1997. Estimasi sistim permintaan dan penawaran daging sapi di provinsi Lampung. Jurnal Ilmu Ternak dan Veteriner. Vol. 3. No.2. Tahun 1998.

Sudaryanto, T., \& E. Jamal. 2000. Pengembangan agribisnis peternakan melalui pendekatan Coorporate Farming untuk mendukung ketahanan pangan nasional. Seminar nasional peternakan dan veteriner. p: 35-47.

Supriadi, H. 2008. Strategi kebijakan pembangunan pertanian di Papua Barat. Analisis kebijakan pertanian. Vol. 6 No. 4.Desember 2008: 352-377.

Suppadit, T., N. Phumkokrak, \& P. Poungsuk. 2006. Adoption of Good Agriculture Practices For Beef Cattl Farming of Beef cattle raising farmers in Tambon Hindard, Dan Khunthot District, Nakhon Rachasima Province, Thailand. KMITL. Sci. Tech. J. Vol. 6. No.2. Juli-Des. 2006.
Tanner, P. J., S. J. Holden, E. Owen, M. Winugroho, \& M. Gill. 2001. Livestock sustaining intensive smallholder crop production through traditional feeding practices for generating high quality manure-compost in Upland Java. Agriculture, Ecosystems and Environment. 84 (2001) 21-30.

Thorne, P. J., \& C. J. Tanner. 2002. Livestock and nutrient cycling in crop animal systems in Asia. Agricultural systems 71 (2002) 111-126.

Utomo, B. N., \& E. Widjaja. 2007. Integrasi ternak sapi bali dengan perkebunan kelapa sawit; 1. Introduksi teknologi inseminasi buatan dan sinkronisasi estrus untuk meningkatkan reproduktifitas ternak. Seminar nasional teknologi peternakan dan veteriner.

Widayati, T. W., \& E. K. Suawa. 2007. Pengembangan agribisnis peternakan sapi potong melalui perbaikan manajemen mikro di kabupaten Sarmi-Papua. Seminar nasional teknologi peternakan dan veteriner. 